\title{
THE EFFECT OF CUSTOMER EXPERIENCE AND CUSTOMER ENGAGEMENT THROUGH CUSTOMER LOYALTY ON SALES REVENUE ACHIEVEMENT AT PT UNITED TRACTORS
}

\author{
Andrie Permadi, Sukardi Silalahi
}

Master Program, Swiss German University, Tangerang, Indonesia

\section{Article Information}

Received: 30 August 2021

Accepted: 13 September 2021

Published: 15 October 2021

DOI: $10.33555 / \mathrm{embm.v9i1.194}$

Corresponding Author:

Andrie Permadi

Bekasi, Indonesia

Email: andriepermadi.nr@gmail.com

ISSN $\quad 2338-8854$

eISSN $2620-9918$

\begin{abstract}
This study aims to examine and discuss the influence of the quality of Customer Experience and Customer Engagement with the mediation of Customer Loyalty which is thought to affect repurchase intention or in other words the achievement of sales revenue as a company performance. The variables in this study were measured through the dimensions of accessibility, service competence, customer recognition, commitment, customer value, thrust, personalization, consistency, perceived quality and customer certainty to make repeat purchases.

The number of respondents involved in this study were 200 respondents, all respondents were United Tractors consumers who had purchased products and services from PT United Tractors. This research is a quantitative approach that uses an instrument in the form of a questionnaire. Research data were analyzed using SEM (Structural Equation Modeling) analysis strategy with the help of SPSS and AMOS programs and the results of the analysis in this study also show that customer loyalty can mediate the effect of Customer Experience and Customer Engagement on Repurchase Intention

Keywords: Customer Behavior, Customer Engagement, Customer Experience, Customer Loyalty, Repurchase Intention, Sales Revenue and Company's Performance
\end{abstract}




\section{Introduction}

In any industry, it will not be separated from the relationship with the name of the customer (Customers), B2C Industry, or even $\mathrm{B} 2 \mathrm{~B}$ at the end of the process will be closely related to the customer. Businessto-business (B2B) customers across industries transform their business models to be more customer-focused and provide complete customer solutions (deLeon \& Chatterjee, 2017). Therefore, the value of a customer or a customer is very important and crucial for a company. With the importance of customer value, the company must have a benchmark or a measure that can state the value of its customer satisfaction level, and in general, currently, the customer satisfaction level value is expressed by a satisfaction index known as the Customer Survey Index (CS Index), which can be obtained by conducting a customer satisfaction survey and it is usually done periodically at least once a year.

CS Index describes the level of customer satisfaction with the service performance of a company-provided to its customers, the higher the CS Index obtained, it can be concluded that the company's service performance to its customers is good or very good. Industrial conditions, in general, continue to change and develop by the needs and demands of customers, as well as demands for service performance of a company. Previously, a high CS index illustrated good customer satisfaction, now the achievement of a high CS index does not make customers loyalists to the company's brands or products.

The impact of not being a customer loyalist to the company's brands and products will make customers swinger in choosing brands and products according to their needs and the impact on the company is not good because it can cause an influence on brand recognition and company sales revenue if it is not anticipated, and repairs made within a certain period may cause "service failure". CS index can no longer be relied on as a benchmark for customers to become loyalists or not, and now the most important thing is how a company can create a memorable experience when customers use its brand and products, then with their own customers will tell a memorable experience. to others, this is what makes the value of a company more valuable, and this is currently known as "Customer Experience".

Customer experience is becoming very important for companies as research analysts write, company strives to create the best customer experience Since 2007, the average customer experience in the industries that Ferreter track has gone up across the board, and the number of truly awful experiences has dropped like a rock "- Michael Gazala, Forrester Research Analyst And Customer experience must be a strategic priority "A growing majority of executives believe that better customer experiences should provide a competitive advantage for their companies" - Survey by Harvard Business Review Analytic Services.

Customer experience is an important driver of business success and competitive advantage (Lemon \& Verhoef, 2016) and has attracted a great deal of attention across private and public sectors, business-tocustomer (B2C) and business-to-business (B2B) markets, recognizing that "what people really desire are not products but satisfying experiences" (Abbot, 1955, p.40), practitioners have sought to better understand customer engagement for some time (Mccoll-kennedy et al., 2015). Customer experience is complex, dynamic, and difficult to capture. It is multidimensional in nature (Lemon \& Verhoef, 2016) encompassing customer responses to all the interactions they have with a firm, with resources external to the firm including other customers. Customer experience is holistic that involves emotional and social, where the experience 
is caused by direct or indirect contact through several touchpoints of contact between the service provider and the customer (Mccoll-kennedy et al., 2015)

Customer experience is generally defined as something holistic, involving cognitive, affective, emotional, social and physical customers in direct or indirect contact with the service provider (Meyer \& Schwager, 2011).

The strategic purpose of measuring customer experience is to use this knowledge to support positive and desirable customer experiences so that a higher level of long-term loyalty is achieved. The firm can see and consider aspects of service delivery based on positive experiences from customers, which then the company determines its entire strategy, and the company can carry out customer experience development with a focus on its capabilities. Business executives consider one of the success factors of business is customer experience, which can be defined as direct and indirect interactions of customers and entrepreneurs, which involve emotional, physical, sensory and social in them (De Keyser et al., 2015). More importantly, the relationship of customer experience with customer value and customer engagement. A better understanding of customer experience may lead to direct changes in daily practices and may also induce a significant change of long-term strategic thinking throughout the organization.

Four guidelines to help businesses better manage customer experience, First, a CXdriven practice should be centered on the individual customer applying a "jobs-to-bedone" mindset. Companies must examine how their customer integrate products and services within their daily lives to improve their relevance to these customers. Second, the scope of the Customer Experience program should extend beyond the dyadic customer-firms relationship and take a service ecosystem perspective. Third, the long-term dynamic nature of Customer experience should become a key focus of marketers. Fourth, accurate Customer experience measurement requires a multimethod approach and cannot be centered around one single measure such as satisfaction on NPS, a combination of methods will enable an accurate understanding of the customer experience and will prove useful to guide managerial decision making (De Keyser et al., 2015). Understanding customer experience and the customer journey over time is critical for the firm, Customers now interact with firms through touchpoints in multiple channels and media, and customer experiences are more social in nature. These changes require firms to integrate multiple business functions, and even external partners, in creating and delivering positive customer experiences (Lemon \& Verhoef, 2016).

\section{Literature Review}

\subsection{Customer Experience}

The company, as a service provider to its customers, will always provide the best service, that customers will get satisfaction with the services provided by the company. The measurement of customer satisfaction can be measured by conducting a satisfaction survey and will get a CS Index as a reference to customer satisfaction values against the company. Companies must be able to make the customer journey a cycle of relationships between the company and its customers, customer satisfaction is often the last goal of the cycle or process of a company's customer journey. In many cases, it is found that customer satisfaction is obtained by customers because the company can provide the things requested or expected by customers and many cases also explain that not a few customers who feel satisfied at the beginning then become dissatisfied because their hopes and desires cannot be fulfilled by the company.

Therefore, companies must be able to build holistic relationships and involve more attitudes from customers on the cognitive, 
affective, emotional, social, and physical responses, this condition is better known as customer experience. It is important for companies to place customer experience in the cycle or process of the company's customer journey. Based on its definition, customer experience is something that is complex, dynamic, and difficult to capture and is a holistic one that involves emotional and social. It is multi-dimensional in nature (Lemon and Verhoef, 2016) and the experience is causes by direct or indirect contact through several touch points of contact between the service provider and the customer (Mccoll-kennedy et al., 2015). Customer experience is created not from elements that the service provider can control but is created from outside elements that they can control, such as the influence of other customers. From a different perspective in one of the articles, it is stated that there are three key domains which can be mentioned as advance customer experience (1) broadening the role of customers in customer experience; (2) taking a practice-based approach to customer experience; and (3) recognizing the holistic, dynamic nature of customer experience across all touch points and over time. Often customers make changes according to their needs, applicable rules and behavior, these changes will have an impact and affect many things, not only themselves but other customers, stakeholders and of course the company as a service provider. Therefore, the organization within the company must be able to adapt to the changes that occur, the companies must examine how their customers have integration with their products and services, the company must have good programs to make a sustainable relationship between the customer and the company and for the long term the company must make Customer experience is one of the key focus of the marketing team, all of these things will only be successful in customer experience activities (De Keyser et al., 2015).
Customers will get the experience at any time and in conditions where the customer deals "touch" the service or the product, brand or organization, which is obtained both before and after the transaction process or service from the company. If we look at other perspectives discussed in In one of the research articles, there are several important elements related to customer experience touch points, which include: atmospheric, technological, communicative, process, employee-customer interaction, customercustomer interaction and product interaction elements (Stein \& Ramaseshan, 2016). And that is no less important in understanding customer experience, customer experience is formed and formed in a long and long process in the relationship between the company and the customer, there is a cross multiple channel interaction and is formed through the relationship between functional and emotional clue. To be able to measure the level of customer experience, in one of the studies it is explained that they introduce the modern conceptual of customer experience as the customer experience quality (EXQ) scale, where the concept is described as the EXQ scale, describing behavioral intention and recommendation better than Customer Satisfaction with CS Its index (Klaus \& Maklan, 2013). The scale measured in the EXQ consists of several elements, product experience, outcome focus, Moment of truth and Peace of mind (POMP).

\subsection{Customer Engagement}

Service performance is often the benchmark for companies to determine the extent to which the level of service the company provides to its customers, in traditional measurements it is measured by conducting customer satisfaction surveys with the customer survey index (CS Index) measurement value, but this measurement pattern has been criticized for failing to capture it. depth of customer response to the performance of services provided by the company. A deeper level to determine customer response by paying attention and 
building customer involvement in processes that involve individual customers and connect with certain brands, where customer engagement is better known as customer engagement (CE) which is one of the important components in relationship marketing.

There are different conceptualizations to define the concept of customer engagement, where practitioners look at it from an organizational perspective and define customer engagement as activities that facilitate repetitive interactions involving emotional, psychological, or physical customers with the company through the brand, whereas academics view from the perspective of customer intensity in participating with organizational representatives. and with other customers in the collaborative knowledge exchange process. Customer Engagement as an activity that describes the intensity of individual participants as customers with and in relationships with organizations consisting of cognitive, emotional, behavioral, and social elements (Vivek, Beatty and Morgan, 2012) customer engagement is advocated particularly from relationship marketing (RM; Vivek, Beatty, \& Morgan, 2010), and service-dominant (SD) logic perspectives (Brodie, Hollebeek, Ilic, \& Juric, 2011), which are cantered on the importance of enduring, co-creative interactions and relationships amongst value generating stakeholders (Hollebeek, 2011).

In the organizational behavior literature, it is also described that involvement has been defined as a task behavior that promotes relationships with work and other people that are expressed physically, cognitively, and emotionally and can stimulate personal development and increase employee motivation. Described in one literature considering the role of affective commitment, calculative commitment, encouragement, and involvement of the customer engagement process for new customers to repeat purchases from certain service brands (Bowden, 2009). From the explanation and literature above, it is important that companies pay attention to customer engagement in their customer journey, so that they can more clearly see the correlation customer experience with customer engagement in a process that is inseparable as relation management.

\subsection{Customer Loyalty}

Customer loyalty has been seen as an important construct for marketing in a company. In general, it can be interpreted that customer loyalty is the strength of the relationship formed between the attitude of the individual as a customer and the company as a service provider and product provider. The relationship between them can be viewed as a dimension by social norms and situational factors (Dick \& Basu, 1994). Several elements that greatly influence the relationship between the two are cognitive, affective, and cognitive, which cannot be separated from the motivational, perceptual, and behavioral consequences between the customer and company relationship.

Another reviewer said in his journal, Loyalty is also positively influenced by service expectations and service confirmation, satisfaction has a positive influence on the four self-determined motivational dimensions - namely, intrinsic regulation, identified regulation, introjection regulation, and external regulation (Söderlund, 2006). Companies can more effectively recognize and reward more valuable customers with-out alienating fewer valuable customers. Companies can obtain authorizations to collect and use individual customer information from customers in exchange for offering enhanced value propositions through loyalty programs. Loyalty programs can encourage customers to give up their personal information in exchange for benefits they will not receive. The quality of the relationship can affect customer loyalty in a business-to-business 
(B2B) context, where the quality of the relationship between the customer and the company is a higher construction consisting of trust, commitment, satisfaction and service quality (Dick \& Basu, 1994).

The quality of the relationship to customer loyalty goes through two levels of relationship quality: the quality of the relationship with supplier employees and the quality of the relationship with the supplier itself. The influence of the dimensions and level of relationship quality on customer loyalty. Only the perceived satisfaction and service quality affect behavioral loyalty (purchase intention) the most extraordinary, only the level of organizational relationship quality affects customer loyalty. The existence of B2B customer loyalty will not be much influenced by the level of quality of employee relations (Rauyruen \& Miller, 2007). Customer loyalty is created from a process in the company's customer journey after a transaction process occurs between the customer and the company, which then results in a relationship between them, which will directly or indirectly have consequences in the company's marketing activities.

\subsection{Repurchase Intention}

In a company, especially in the marketing department, one of the core concepts is customer experience, where $\mathrm{CX}$ is used as a basis for predicting customer purchase intentions. The results of one study concluded that only emotional experiences and social experiences that customers have have a significant positive impact on purchase intention (Nasermoadeli et al., 2013). The intention to buy back customers is influenced by seven important factors: service quality, equity and value, customer satisfaction, past loyalty, expected switching costs and preferred brand (Phillip et al., 2003). Past purchase loyalty is not directly related to customer satisfaction or current brand preference. The intention to repurchase occurs after the consumer makes a purchase, it can be due to having consumed it so that he intends to repurchase the same product or service. In general, the definition of repurchase intention is a desire or desire that arises in a customer to buy products and services that he likes and has previously buy it based on the results of evaluation of the suitability of product and service performance with consumer expectations (Hellier et al., 2003). There are several factors that can influence consumers in purchase intentions, both internal factors from within customers, namely trust and consumer attitudes. towards products and services, and external factors, the attitudes of others and the situation of the place of purchase (Kotler, 2008: 242).

Purchase intention is influenced by the level of customer experience, the better experience the customer gets, the greater the opportunity for interest to make another purchase. The purchase intention of the customer will then become the purchasing decision process, after the customer gets to know the product, finds out information related to the product, evaluates alternatives that can meet customer needs and then makes a purchase decision after experiencing a positive experience of the products and services provided by the company. The decision to make purchases made by customers becomes an activity that provides value for the company in the form of achieving company performance in terms of achieving sales revenue for products and services from the company.

\subsection{Research Framework}

The heavy equipment industry is a B2B industry sector, which in general, customers can be divided into several groups, namely customers with key account management, medium customers, and retail customers. Each customer has its characteristics and characteristics in the business process with the company. Apart from the differences in existing business processes, there is an important thing that the three groups have in common, namely that they are still the 
company's customers. Where they as customers, will have the expectation to be treated the same as customers and for the company most importantly for all customers can have the right to get a good experience.

Talking about customer experience cannot be determined and regulated by the company, because the experience can only be felt by customers and customers can express their experience in various forms and ways, which of course the company hopes for the form of experience is to convey positive things to other customers and continuously. keep doing transactions with the company. What the company needs to do so that the expectation of a good customer experience can make the company good performance, especially in terms of sales achievement, this study will be discussed in this literature. To get started, we must know the understanding and connection of customers, customer journeys, customer feedback, customer satisfaction, excellent customer service, and customer experience itself. After understanding this, it can be studied more deeply by analyzing the achievement of a good customer experience which will improve company performance in terms of achieving sales opinions that will also increase. What touchpoints should be the focus of the company so that this can be insight and solution to transform the company's business.

The first hypothesis we recognize, and we understand the meaning of customers for the company, customer journey, and customer experiences. Customers are people or companies who buy and use products or services provided by the company, in the process, and in their journey, customers will feel good or bad impressions when using the products and services they purchased. Then there is a process that keeps repeating itself from the start of the customer searching for products, the company doing promotion and marketing until the transaction or buying and selling process occurs, where the customer gets the benefits of the product and the company gets income from the products it sells, that process is more we know as the customer journey as a process that cannot be separated from the relationship between the customer and the company.

The hypothesis that we need to do, this is an important series in the study that we are currently doing, namely after the company can get a good customer experience, what things affect and what things should be considered by the company so that a good customer experience can ensure it happens. business transactions that continue to occur and make the company's performance better in terms of sales achievement. For that we need to examine more deeply after the customer experience process is achieved, where customers get a good impression of the company's products and services, how long can this impression be maintained? Will the good impression remain? What things the company needs to do so that the impression is there even the customer will get a much better impression. After the customer gets a good experience for the business transaction that occurs, then the real customer expectations will automatically increase as well and so on, so that if we depend on customer expectations, each time these expectations will increase. So that to keep customer expectations from increasing over time, we must understand that expectations exist because customers always want to get the best results and because of previous expectations the company has been able to provide, therefore the company must be able to manage an impression. good that has been felt by the customer by engaging the customer and the company.

With a well-formed engagement, the company can convince customers, the results that will be obtained will always provide an experience for the customer and most importantly for customer engagement that occurs, the company and the customer 
have the same commitment, to jointly make improvements and development so that the results obtained are for customers will get a good impression and for the company, there will be business transactions on an ongoing basis. The hypothesis that will be carried out next and the definite relationship of repurchase intention to company performance is important, in this study it is assumed that repurchase intention is the assurance of customers to continue making transactions with the company not only at the level of desire but already at the stage where customers make transactions, and this This is the benchmark for the company's achievement in measuring its sales achievement. Based on the explanation of the related variables above, the structural model of research framework of this research can be seen in the following framework figure.

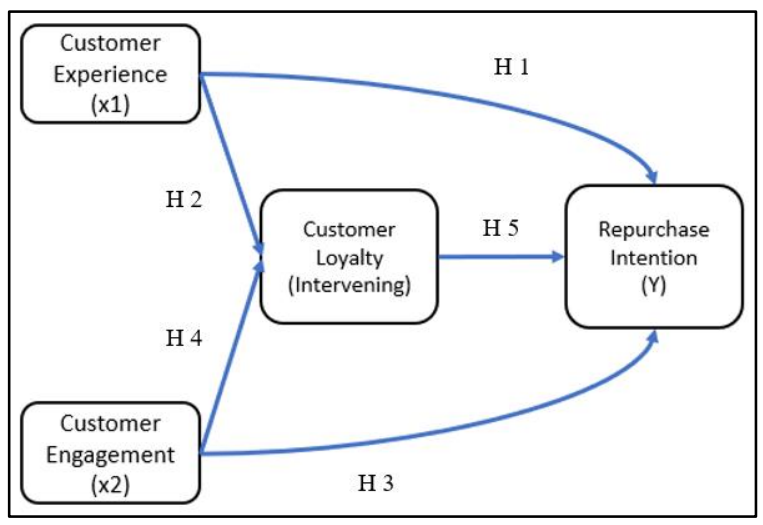

Figure 1. Research Model

\section{Research Method}

\subsection{Type of Study}

The method used for this research is descriptive quantitative method with a probability sampling, where the investigation is causality, because the causality relationship between the independent and dependent variables will be tested and they can also be used to look at associations or relationship between variables (Drummond \& Murphey-Reyes, 2017). The research I did was to be able to answer the problems that currently exist in the company through testing existing hypotheses. The object of this research is the repurchase intention of United Tractors service users based on customer experience and customer engagement felt by customers and influenced by customer loyalty to the company.

This study uses quantitative methods, where methods that use objective and statistical measurements are then carried out. Mathematical or numerical analysis of all research data, where data is obtained through questionnaires or surveys or by manipulating existing statistical data with computational techniques. This study also focuses on collecting numerical data on a group of people or explaining certain phenomena, so that with this quantitative method the researcher can identify the factors that most influence the variables that lead to customer purchase intentions. This research also uses an electronic method where questionnaires and surveys will be distributed online or internet survey methods that are considered effective applications are currently carried out and this research is also assisted by a paid survey application to help researchers design questions and summarize the overall results of the questionnaire. This study is designed with a research structure that is structured in such a way that the author can get answers to research questions, the authors provide the scope of research.

\subsection{Data Sample}

The current study focuses on individual analysis, especially those who already know and conduct business transactions with companies Individuals describe in more detail their behaviour and characteristics (age, gender, attitude, religion, etc.) According to Bryman (2012), the population is the universe of units from which the sample is to be selected. It is also defined as the total of all elements that share some common set of characteristics that contains the creation for the objective of marketing research problems (Malhotra, 2017). In this study, the population will be limited to the 
category of United Tractors customers who have or have transacted with the company, the researcher chose to do non-experimental research, where the researcher was only able to manage general variables through respondent grouping, selecting respondents as samples, making a list of questions and training interviewers with probability or random sample (stratified random).

\subsection{Data Sources \& Collection}

The Data in this study is primary data, which is data obtained from research results direct empirically to the direct or all study objects that have been previously determined. To obtain secondary data needed in research, researchers can perform several data collection techniques. There are several types of collection methods for quantitative data, and this study researcher used Survey or Questionnaires method where information or data collected from respondents can use a questionnaire or questionnaire as a data collection instrument which is carried out through direct distribution or through intermediaries such as web or online media. Research using survey methods can be described as scientific research whose data are collected from a selected sample of the entire population.

\subsection{Data Analysis Technique}

Data Analysis is an activity after data from all respondents or other sources have been collected and the data used in this study use quantitative data which means the value of available data is in the form of numbers or calculations, each data set has an exclusive numeric value that is related to each other. This type of data contains information that can be calculated by statistical and mathematical calculations.

Descriptive statistics is the process of analyzing data with statistical methods by describing, showing and summarizing raw data through summary statistics, graph a table, the goal is to facilitate data analysis. Descriptive statistics such as max, min, means, standard deviations and variances were obtained for the interval-scaled independent variables and dependent variables (Sekaran and Bougie, 2010). Descriptive analysis in this study was carried out by calculating the average value (mean) and standard deviation for further categorization based on low, medium and high categories according to the categorization technique by Uma (2012). Because the instrument in this study has a scale of 1-5, which means the score of respondents' answers has the lowest value of 1 and the highest 5 , then based on the categorization rules of Uma (2012). Descriptive statistics are useful because they allow you to understand a group of data much more quickly and easily compared to just staring at rows and rows of raw data values.

\subsection{Data Processing Procedures}

Data preparation is a pre-processing step that involves cleansing, transforming, and consolidating data. In other words, it is a process that involves connecting to one or many different data sources, cleaning dirty data, reformatting, or restructuring data, standardizing data formats, enriching source data, removing outliers and finally merging this data to be consumed for analysis. Most researchers choose to use a database or statistical analysis program (e.g. Microsoft Excel, SPSS, AMOS) that they can format to fit their needs and organize their data effectively. Once the data has been entered, it is crucial that the researcher check the data for accuracy. In the research process, one of the most important processes is the screening data, the quality of good data analysis is influenced by the quality of the initial data filtering and treatment

Pre-test is a questionnaire test on a small number of samples with the aim of identifying and eliminating errors in the questionnaire (Malhotra, 2007). In this study, a pre-test was conducted on 17 samples that met the requirements. For the reliability test, Cronbach's Alpha value 
obtained from the data analysis process can be used as an indicator reference for consistent research data. Meanwhile, for validity, the component matrix of the output factor analysis results is used as an indicator that shows the distribution of sample data on the formed factors. To process the respondent data, researcher use Structural Equation Modelling (SEM) with AMOS software. SEM analysis technique is used because the complexity of the conceptual model used in this study. Structural Equation Modelling (SEM) defined as statistical method used to test interrelated relationships among observed variables, between measurement and latent variables, with the same basic goal of providing a quantitative test of a theoretical model hypothesized by the researcher. More precisely, various theoretical models can be evaluated in SEM, hypothesizing how sets of variables describe constructs and how those constructs are interrelated. This study examines the relationship between online reviews and impulsive buying, with the role of browsing and impulsiveness (Zhang et al., 2018). SEM test is conducted to test the relationship of 6 measurement variables given by reference journal. There are two major types of variables in SEM, namely unobserved (latent) variables and observed variables.

Unobserved or latent variables (construct or factors) are variables that cannot be directly observed or calculated, and thus are derived from a collection of observable variables that are measured using tests, surveys, and other tools. In this research, the latent variable includes Customer Experience, Customer Engagement, Customer Loyalty and repurchase Intention. While, the observed variables, measured, or indicator variables are a set of variables which are used to define or infer the latent or construct variable. One of the advantages, as mentioned before, is SEM can help researcher to test complex set of regression equations simultaneously, which often called Onestep Approach (Malkanthie, 2019).
In this research, we use Two-step Approach SEM as the alternative, refer to the previous study by Zhang et al. (2018) as well as suggestion in Wijanto (2015). There are two stages of procedure in Two-step Approach: the measurement and structural model (Zhang et al.,2018). In the first step, researcher will conduct a measurement model analysis to see the fit towards data. Here, researcher will confirm whether every latent variable is modelled as a factor that is standardized based on related observed variables. The measurement model on SEM uses Confirmatory Factor Analysis (CFA) (Wijanto, 2015). The next step called the structural model analysis. It shows the relationships between the latent variables. The relationships are usually linear, even though SEM allows the presence of nonlinear relationship (Wijanto, 2015).

\section{Result and Discussion}

The results of this study include the results of descriptive analysis of respondents' characteristics and the results of SEM analysis. Descriptive analysis of the characteristics of the respondents is used to describe the characteristics of the respondents in terms of gender, age, education level, the respondent's length of service in his company, the type of transaction carried out and the last time the respondent transacted with PT United Tractors. In addition to a descriptive analysis of the characteristics of the respondents, the data in this study were also processing by Structural Equation Modeling (SEM) Analysis Technique. The results of this SEM analysis are then used to test the effect of customer experience and customer engagement on repurchase intention mediated by customer loyalty. The number of respondents used in this study were 200 respondents. All respondents are consumers who have purchased PT United Tractors products and services. Based on the results of descriptive analysis in this study, the following is a description of the characteristics of the respondents based on gender, age, education level, last 
transaction in PT United Tractors products and services, the last time the respondent made a transaction and the respondent's length of service in the company:

Table 1. Description of Respondents Characteristics

\begin{tabular}{|c|c|c|c|}
\hline Characteristics & Category & Frequency (f) & Percentage $(\%)$ \\
\hline \multirow{2}{*}{ Gender } & Male & 157 & 78.5 \\
\hline & Female & 43 & 21.5 \\
\hline \multirow{5}{*}{ Age } & $17-25$ yeras old & 23 & 11.5 \\
\hline & 26 - 35 yeras old & 95 & 47.5 \\
\hline & 36 - 45 yeras old & 53 & 26.5 \\
\hline & $46-55$ yeras old & 27 & 13.5 \\
\hline & $>56$ yeras old & 2 & 1.0 \\
\hline Education & Under High School & 2 & 1.0 \\
\hline \multirow{4}{*}{$\begin{array}{l}\text { Education } \\
\text { Job Experience }\end{array}$} & High School & 46 & 23.0 \\
\hline & Diploma & 32 & 16.0 \\
\hline & Barchelor Degree & 120 & 60.0 \\
\hline & $<5$ years & 97 & 48.5 \\
\hline \multirow{4}{*}{$\begin{array}{l}\text { Job Experience } \\
\text { Last Transaction } \\
\text { Purpose }\end{array}$} & $6-10$ years & 43 & 21.5 \\
\hline & $11-20$ years & 42 & 21.0 \\
\hline & $>21$ years & 18 & 9.0 \\
\hline & Permintaan Jasa Mekanik & 25 & 12.5 \\
\hline \multirow{5}{*}{$\begin{array}{l}\text { Last Transa } \\
\text { Purpose } \\
\text { Last } \\
\text { Transaction }\end{array}$} & Pembelian Alat Berat & 17 & 8.5 \\
\hline & Pembelian Spare Parts & 132 & 66.0 \\
\hline & Menghubungi Contact Center & 18 & 9.0 \\
\hline & Menggunakan Mobile Applikasi & 8 & 4.0 \\
\hline & $1-3$ years ago & 63 & 31.5 \\
\hline Time & in this year (2021) & 105 & 52.5 \\
\hline \multirow[t]{2}{*}{ Transaction } & $4-5$ years ago & 6 & 3.0 \\
\hline & $>5$ years ago & 26 & 13.0 \\
\hline
\end{tabular}


In SEM analysis, measurement model testing (CFA Analysis) is used to test the validity and reliability of indicators on each construct. Testing the measurement model on each construct consists of several stages, consist of (1) Construct Validity Testing and (2) Construct Reliability Testing. The results of the analysis show that all indicators are valid in measuring their constructs so that all indicators in the CFA model can be used to measure exogenous constructs. The test is continued on the construct reliability test by looking at the $\mathrm{CR}$ and AVE values of each construct.

Tabel 2. Construct Validity and Reliability Test Results

\begin{tabular}{|c|c|c|c|c|c|c|}
\hline Variebel & Indikator & $\lambda$ & Validitas & AVE & CR & Reliabilitas \\
\hline \multirow{6}{*}{$\begin{array}{l}\text { Customer } \\
\text { Experience }\end{array}$} & CX1 & 0.867 & valid & 0.785 & 0.966 & reliabel \\
\hline & $\mathrm{CX} 2$ & 0.894 & valid & & & \\
\hline & CX5 & 0.885 & valid & & & \\
\hline & CX7 & 0.895 & valid & & & \\
\hline & CX8 & 0.887 & valid & & & \\
\hline & CX9 & 0.887 & valid & & & \\
\hline \multirow{6}{*}{$\begin{array}{l}\text { Customer } \\
\text { Engagement }\end{array}$} & CE6 & 0.847 & valid & 0.817 & 0.967 & reliabel \\
\hline & CE5 & 0.918 & valid & & & \\
\hline & CE4 & 0.921 & valid & & & \\
\hline & CE3 & 0.910 & valid & & & \\
\hline & CE2 & 0.914 & valid & & & \\
\hline & CE1 & 0.910 & valid & & & \\
\hline \multirow{5}{*}{$\begin{array}{l}\text { Customer } \\
\text { Loyalty }\end{array}$} & CL7 & 0.864 & valid & 0.803 & $0.953 \quad 1$ & reliabel \\
\hline & CL6 & 0.870 & valid & & & \\
\hline & CL5 & 0.904 & valid & & & \\
\hline & CL4 & 0.921 & valid & & & \\
\hline & CL3 & 0.920 & valid & & & \\
\hline \multirow{4}{*}{$\begin{array}{l}\text { Repurchase } \\
\text { Intention }\end{array}$} & RI1 & 0.920 & valid & 0.862 & 0.932 & reliabel \\
\hline & RI2 & 0.941 & valid & & & \\
\hline & RI3 & 0.938 & valid & & & \\
\hline & RI4 & 0.915 & valid & & & \\
\hline
\end{tabular}

Based on data of the analysis in the tables, the results of the analysis show that the AVE values of all constructs have been $>0.5$ and the $\mathrm{CR}$ of all constructs have been
$>0.7$, which means that all constructs have met the required composite reliability criteria. 


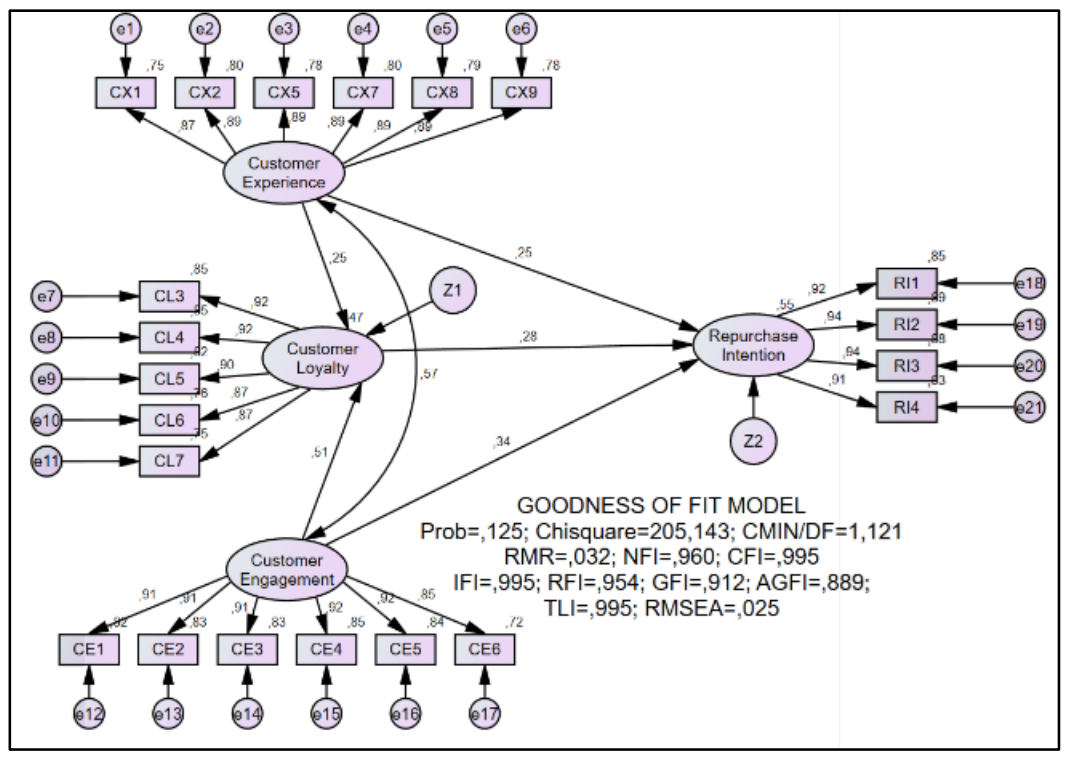

Figure 2. Results of Full Structural Model

Structural model testing is used to test the research hypothesis. The stages in the structural model testing include the structural model formation stage, the structural model feasibility test and the significance test of the effect of exogenous variables on endogenous variables.
Structural model fit test in SEM analysis is done by looking at several criteria of Goodness of fit model such as Chi Square value, probability, df, GFI, AGFI, TLI, CFI RMSEA and RMR. The following is a summary of the results of the goodness of fit model testing after modifications can be seen in the following table:

Table 3. Goodness of Fit Model

\begin{tabular}{|c|c|c|c|}
\hline Goodness of fit index & $\begin{array}{c}\text { Cut } \\
\text { of Value }\end{array}$ & $\begin{array}{c}\text { Result } \\
\text { Analysis }\end{array}$ & $\begin{array}{c}\text { Model } \\
\text { Evaluation }\end{array}$ \\
\hline$X^{2}$ chi square & $<1215,563$ & 205,143 & Good Fit \\
\hline significancy probability & $\geq 0,05$ & 0,125 & Good Fit \\
\hline RMSEA & $\leq 0,08$ & 0,025 & Good Fit \\
\hline GFI & $\geq 0,90$ & 0,912 & Good Fit \\
\hline AGFI & $\geq 0,90$ & 0,889 & Marginal Fit \\
\hline CMIN/DF & $\leq 2,00$ & 1,121 & Good Fit \\
\hline TLI & $\geq 0,95$ & 0,995 & Good Fit \\
\hline CFI & $\geq 0,95$ & 0,995 & Good Fit \\
\hline
\end{tabular}


In SEM analysis, the coefficient of determination shows the influence of all exogenous variables on endogenous variables. The coefficient of determination is seen from the value of the squared multiple correlation.

Table 4. Coefficient of Determination

\begin{tabular}{ll}
\hline Variables & Estimate \\
\hline $\mathrm{CL}$ &, 465 \\
\hline $\mathrm{RI}$ &, 554 \\
\hline
\end{tabular}

The results of the analysis show that the value of the squared multiple correlation of the customer loyalty (CL) variable is 0.465 , indicating that the influence of customer experience and customer engagement on customer loyalty is $46.5 \%$, while the remaining $53.5 \%$. customer loyalty variance is influenced by other factors outside of customer experience and customer engagement. Furthermore, for the repurchase intention (RI) variable, the $\mathrm{R}$ square value obtained is 0.554 indicating the large contribution of customer experience, customer engagement and customer loyalty to repurchase intention is $55.4 \%$, while the remaining $44.6 \%$ variance of repurchase intention is influenced by other factors in beyond customer experience, customer engagement and customer loyalty.

In this study, the customer loyalty variable acts as a variable that mediates the indirect effect of customer experience, customer engagement to the repurchase intention. To examine the role of customer loyalty in mediating the indirect effect of customer experience and customer engagement on repurchase intention. then the mediation effect can be tested using the Sobel test.

The hypothesis used in this test is as follows:

Ho: Customer loyalty cannot mediate the effect of customer experience and customer engagement on repurchase intention.

Ha: Customer loyalty can mediate the effect of customer experience and customer engagement on repurchase intention.

With a significance level of $5 \%$, Ho is rejected if the $\mathrm{p}$ value of the Sobel test result is $<0.05$ and Ho is not rejected if the $\mathrm{p}$ value of the Sobel test result is $>0.05$.

Table 5. Sobel Test Result

\begin{tabular}{llll}
\hline $\begin{array}{l}\text { Indirect } \\
\text { Path }\end{array}$ & T Statistic & P Value & Result \\
\hline $\begin{array}{l}\mathrm{CX} \rightarrow \\
\mathrm{CL} \rightarrow \mathrm{RI}\end{array}$ & 2,345 & 0,0085 & $\begin{array}{l}\text { Significantly } \\
\text { Mediate }\end{array}$ \\
\hline $\mathrm{CE} \rightarrow$ & 3,054 & 0,0011 & $\begin{array}{l}\text { Significantly } \\
\text { Mediate }\end{array}$ \\
$\mathrm{CL} \rightarrow \mathrm{RI}$ & & & \\
\hline
\end{tabular}

The hypothesis in this study was tested based on the results of SEM analysis. The following are the results of hypothesis testing based on the results of the SEM analysis that has been carried out in this study: 
Table 6. Summary of Hypothesis Testing Results

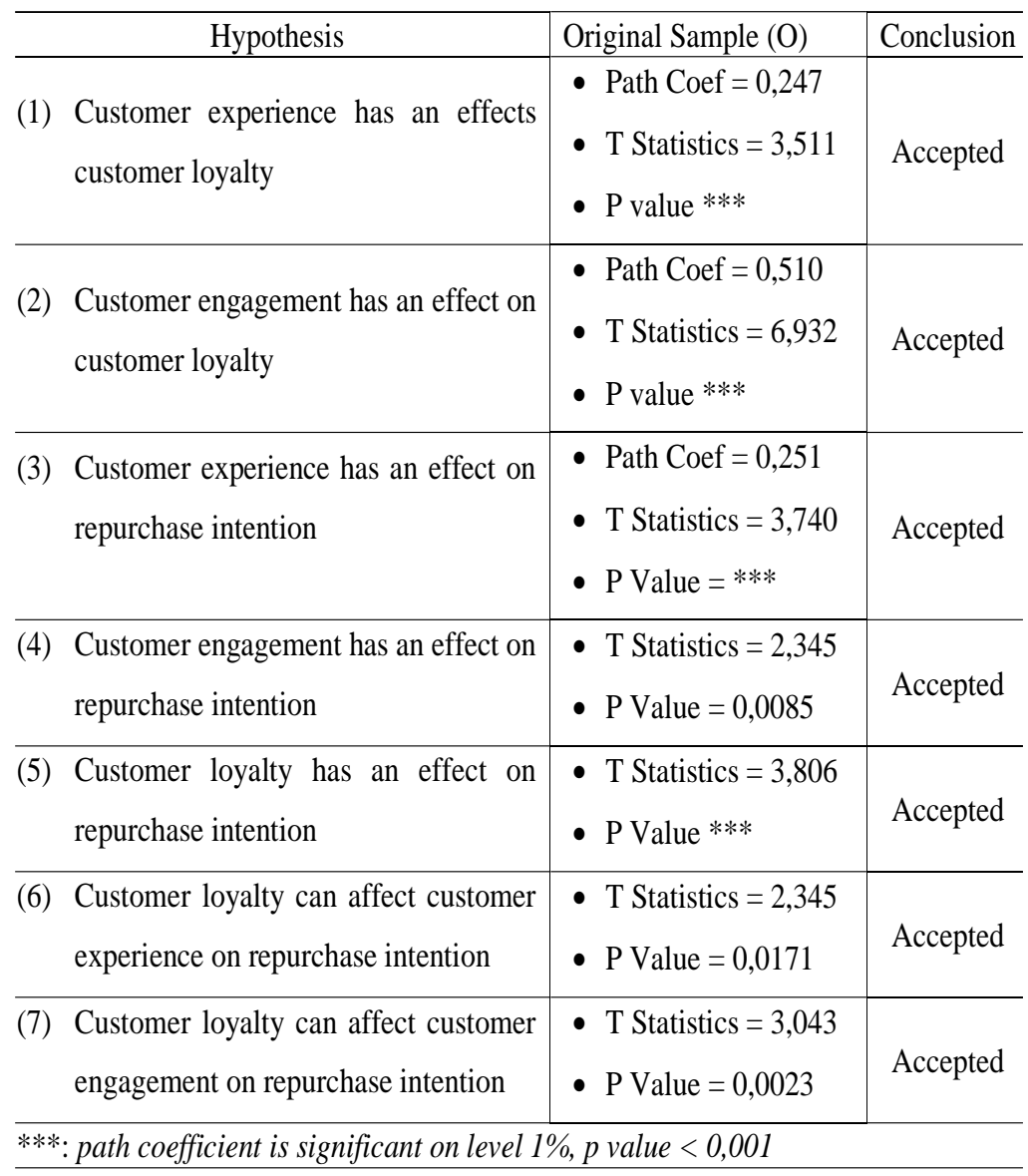

\section{Conclusion}

Based on the data analysis, the effect of Customer Experience, Customer engagement on Customer Loyalty which affect Repurchase Intention several conclusions are drawn as the hypothesis. This research studies the relationship between variables (Customer Experience, Customer Engagement, Customer Loyalty and Repurchase Intention)

The conclusions obtained from the results of this study are as follows:

1. Customer experience has a positive and significant impact on customer loyalty, the higher the consumer experience with the products of PT United Tractors, the higher the consumer loyalty.

2. Customer Engagement has a positive and significant impact on customer loyalty, the higher the consumer engagement to the products of PT United Tractors, the higher the consumer loyalty.

3. Customer experience has a positive and significant impact on repurchase intention, the higher the consumer experience with PT United Tractors products, the higher consumer interest in repurchasing PT United Tractors products.

4. Customer Engagement has a positive and significant impact on repurchase intention, the higher the consumer's attachment to PT United Tractors products, the higher consumer interest in repurchasing PT United Tractors products.

5. Customer Loyalty has a positive and significant impact on repurchase intention, the higher consumer loyalty to PT United Tractors products, the higher consumer interest in repurchasing PT United Tractors products. 
6. Customer Loyalty can mediate the influence of Customer Experience on Repurchase Intention. The higher the consumer experience in purchasing the products of PT United Tractors, the higher the consumer's interest in repurchasing the products of PT United Tractors.

7. Customer Loyalty can mediate the influence of Customer Engagement on Repurchase Intention. The higher the consumer's attachment to the products of PT United Tractors, the higher the interest of consumers to repurchase the products of PT United Tractors.

\section{References}

Ali, H. (2019). Building repurchase intention and purchase decision: brand awareness and brand loyalty analysis (case study private label product in Alfamidi Tangerang). Saudi Journal of Humanities and Social Sciences, 04(09), pp. 623-634. https://doi.org /10.36348/sjhss.2019.v04i09.009

De Keyser, A., Lemon, K. N., Klaus, P., \& Keiningham, T. L. (2015). A framework for understanding and managing the CX. Working Paper Series, 15(121), pp. 1-47.

deLeon, A. J., \& Chatterjee, S. C. (2017). B2B relationship calculus: quantifying resource effects in service-dominant logic. Journal of the Academy of Marketing Science, 45(3), pp. 402427. https://doi.org/10.1007/s11747015-0467-0

Dick, A. S., \& Basu, K. (1994). Customer loyalty: Toward an integrated conceptual framework. Journal of the Academy of Marketing Science, 22(2), pp. 99-113. https://doi.org/10.1177 /0092070394222001

Drummond, K., \& Murphey-Reyes,, A. (2018). Quantitative research designs: Experimental, quasi-experimental, and descriptive. In Nutrition Research:
Concepts and Applications (pp. 155183). Jones \& Bartlett Learning.

Hollebeek, L. (2011) Exploring customer brand engagement: definition and themes, Journal of Strategic Marketing, 19(7), pp. 555-573, DOI: 10.1080/0965254X.2011.599493

Klaus, P., \& Maklan, S. (2013). Towards a better measure of customer experience. International Journal of Market Research, 55(2), pp. 227-246. https:// doi.org/10.2501/IJMR-2013-021

Lemon, K. N., \& Verhoef, P. C. (2016). Understanding customer experience throughout the customer journey. Journal of Marketing, 80(6), pp. 6996. https://doi.org/10.1509/jm.15 .0420

McColl-Kennedy, J.R., Gustafsson, A., Jaakkola, E., Klaus, P., Radnor, Z.J., Perks, H. and Friman, M. (2015), Fresh perspectives on customer experience. Journal of Services Marketing, 29(6/7), pp. 430435. https://doi.org/10.1108/JSM-012015-0054

Meyer, C., \& Schwager, A. (2007). Understanding customer experience. Harvard Business Review, (February). Retrieved from https://hbr.org/2007 /02/understanding-customerexperience

Moura e Sá, P., \& Amorim, M. (2017). A typology of customer-to-customer interaction and its implications for excellence in service provision. Total Quality Management and Business Excellence, 28(9-10), pp. 1183-1193. https://doi.org/10.1080/14783363.201 7.1309121

Nasermoadeli, A., Ling, K. C., \& Maghnati, F. (2013). Evaluating the impacts of customer experience on purchase intention. International Journal of Business and Management, 8(6). pp. 128-138. https://doi.org/10.5539 /ijbm.v8n6p128 
Nuari, E. S., Nurkhin, A., \& Kardoyo, K. (2019). Analisis determinan pemanfaatan Edmodo dengan menggunakan unified theory of acceptance and use of technology (UTAUT). Jurnal Pendidikan Akuntansi Indonesia, 17(1). pp. 57-73. https://doi.org /10.21831/jpai.v17i1.26337

Paul, R., \& Ponnam, A. (2018). Teaching customer experience quality and its significance in retail management: a role playing game using Chinese puzzle 'Tangram.' Decision Sciences Journal of Innovative Education, 16(2), pp. 126-139. https://doi.org /10.1111/dsji.12147

Phillip, K., Gus, M., Rodney, A., \& John, A. (2003). Customer repurchase intention. European Journal of Marketing, 37(11), pp. 1762-1800.

Rahmawaty, P. (2015). Pengaruh variasi produk, harga, dan customer experience terhadap keputusan pembelian ulang roti Breadtalk Yogyakarta. Jurnal Ilmu Manajemen, 12(1), pp. 89-98. https://doi.org /10.21831/jim.v12i1.11744

Rauyruen, P., \& Miller, K. E. (2007). Relationship quality as a predictor of B2B customer loyalty. Journal of Business Research, 60(1), pp. 21-31. https://doi.org/10.1016/j.jbusres.2005. 11.006

Söderlund, M. (2006). Measuring customer loyalty with multi-item scales: A case for caution. International Journal of Service Industry Management, 17(1), pp. 76-98. https://doi.org/10.1108 /09564230610651598

Stein, A., \& Ramaseshan, B., (2016). Towards the identification of customer experience touch point elements. Journal of Retailing and Consumer Services, 30(May), pp. 8-19. https://doi.org/10.1016/j.jretconser.20 15.12.001
Sukoco, B. M., \& Hartawan, R. A. (2011). Pengaruh pengalaman dan keterikatan emosional pada merk terhadap loyalitas konsumen. Jurnal Manajemen Teori dan Terapan, 4(3), pp. 1-12 https://doi.org/10.20473/jmtt.v4i3.2421

Taherdoost, H. (2017). Determining sample size; How to calculate survey sample size. International Journal of Economics and Management Systems, 2(2), pp. 237-239. http://www.iaras.org /iaras/journals/ijems

Taherdoost, H. (2018). Sampling methods in research methodology: How to choose a sampling technique for research. International Journal of Academic Research in Management, 5(2), pp. 18-27.

Wijaya, N., \& Dharmayanti, D. (2017). Pengaruh brand performance terhadap repeat purchase dengan competitive advantage dan customer engagement sebagai variabel intervening pada pengguna sepeda motor Honda di Surabaya. Jurnal Strategi Pemasaran, $4(2)$.

Witell, L., Kowalkowski, C., Perks, H., Raddats, C., Schwabe, M., Benedettini, O., \& Burton, J. (2020). Characterizing customer experience management in business markets. Journal of Business Research, 116(August), pp. 420-430. https:// doi.org/10.1016/j.jbusres.2019.08.050

Zaenuri, M., \& Sutanto, A. (2020). Analisis pengaruh customer experience terhadap pembelian ulang (Studi kasus pada konsumen restoran gudeg $\mathrm{Yu}$ Djum Jln. Kaliurang Km. 5 Koncoran Gg. Sri Katon 2 Yogyakarta). Jurnal Fokus Manajemen Bisnis, 5(1), pp. 8495. https://doi.org/10.12928/fokus .v5i1.1618 